\title{
MANAJEMEN KEUANGAN PONDOK PESANTREN
}

\author{
MIFTAHOL ARIFIN \\ STIT Al-Karimiyyah Sumenep \\ miftah.abibilqist@gmail.com
}

\begin{abstract}
There are three factors that has significant role in the organization of Islamic boarding school system. Those are, management as the factor of efforts, the organization as the factor of Facility, and the administration as the factor of intention. These three factors give direction and cohesion in defining, controlling, organizing, supervising and assessing the implementation of the policies in an effort to organize educational activities in accordance with the aim of every Islamic boarding school.

One of the components of management in an effort to Islamic boarding school is financial management. Financial management of the Islamic boarding school is an activity undertaken in order to achieve the purpose of boarding schools that had planned to develop and manage resources and sources of funding and the potential held in the boarding school system effectively and efficiently. This activity can be started from the planning, organizing, implementing up to scrutiny. In the financial management at the school began with budget planning up to monitoring and financial accountability.

Financial management of the Islamic boarding school is one of the substances management of educational institutions which will in turn determine the smooth operation of the Islamic boarding school. As the case on the substance of education in general management, financial management activities of the boarding school should be done through the process of planning, organizing, directing, coordinating, monitoring or controlling. Some activities such as financial management and assign an activity to obtain funding sources, utilization of funds, reporting, inspection and accountability.
\end{abstract}

\section{Abstrak}

Ada tiga faktor yang berperan dalam sistem penyelenggaraan Pondok Pesantren yaitu, manajemen sebagai faktor upaya, organisasi sebagai faktor Sarana, dan administrasi sebagai faktor karsa. Ketiga faktor ini memberi arah dan perpaduan dalam merumuskan, mengendalikan, penyelenggaraan, mengawasi serta menilai pelaksanaan kebijakan kebijakan dalam usaha menyelenggarakan kegiatan pendidikan yang sesuai dengan tujuan setiap Pondok Pesantren.

Salah satu komponen manajemen sebagai upaya dalam pondok pesantren adalah manajemen keuangan. Manajemen keuangan pondok pesantren merupakan kegiatan yang dilakukan guna mencapai tujuan pondok pesantren yang telah direncanakan dengan mengembangkan dan mengelola sumber daya dan sumber dana serta potensi-potensi yang dimiliki dalam sistem pondok pesantren secara efektif dan efisien. Kegiatan 
ini dapat dimulai dari perencanaan, pengorganisasian, pelaksanaan sampai dengan pengawasan. Dalam manajemen keuangan di sekolah tersebut dimulai dengan perencanaan anggaran sampai dengan pengawasan dan pertanggung jawaban keuangan.

Manajemen keuangan pondok pesantren merupakan salah satu substansi manajamen lembaga pendidikan yang akan turut menentukan kelancaran kegiatan pondok pesantren. Seperti halnya yang terjadi pada substansi manajemen pendidikan pada umumnya, kegiatan manajemen keuangan pondok pesantren seyogyanya dilakukan melalui proses perencanaan, pengorganisasian, pengarahan, pengkoordinasian, pengawasan atau pengendalian. Beberapa kegiatan manajemen keuangan berupa kegiatan memperoleh dan menetapkan sumber-sumber pendanaan, pemanfaatan dana, pelaporan, pemeriksaan dan pertanggung jawaban.

\section{Kata Kunci: Pondok Pesantren, Manajemen Keuangan}

\section{Pendahuluan}

Menurut Maysarah dikutip oleh Sulistyorini menjelaskan bahwa manajemen keuangan adalah suatu proses melakukan kegiatan mengatur keuangan dengan menggerakkan tenaga orang lain. Kegiatan ini dapat dimulai dari perencanaan, pengorganisasian, pelaksanaan sampai dengan pengawasan. Dalam manajemen keuangan di sekolah tersebut dimulai dengan perencanaan anggaran sampai dengan pengawasan dan pertanggung jawaban keuangan ${ }^{1}$.

Menurut Depdiknas manajemen keuangan merupakan tindakan pengurusan/ ketatausahaan keuangan yang meliputi pencatatan, perencanaan, pelaksanaan, pertanggungjawaban dan pelaporan. Dengan demikian, manajemen keuangan sekolah dapat diartikan sebagai rangkaian aktivitas mengatur keuangan sekolah mulai dari perencanaan, pembukuan, pembelanjaan, pengawasan dan pertanggungjawaban keuangan sekolah'2. Mulyasa mengatakan bahwa manjemen keuangan sekolah merupakan bagian dari kegiatan pembiayaan pendidikan, yang secara keseluruhan menuntut kemampuan sekolah untuk merencanakan, melaksanakan dan mengevaluasi serta mempertanggungjawabkan secara efektif dan transparan ${ }^{3}$.

Mengingat antara sekolah dan pondok pesantren memiliki kesamaan substansi dan kesamaan visi-misi dari setiap instansi, maka berdasarkan defenisi di atas penulis dapat menyimpulkan bahwa manajemen keuangan pondok pesantren merupakan kegiatan yang dilakukan guna mencapai tujuan pondok pesantren yang telah direncanakan dengan mengembangkan dan mengelola sumber daya dan sumber dana serta potensi-potensi yang dimiliki dalam sistem pondok pesantren secara efektif dan efisien.

\footnotetext{
${ }^{1}$ Sulistyorini, Manajemen Pendidikan Islam, (Yogyakarta: Teras, 2009), 130-131

${ }^{2}$ Akhmad Sudrajat, Konsep dasar manajemen keuangan sekolah, (Pustaka Rizki Putra, 2013), 36.

${ }^{3}$ E. Mulyasa, Manajemen Berbasis Sekolah, (Bandung: Remaja Rosdakarya, 2006), 194
} 
Manajemen keuangan pondok pesantren merupakan salah satu substansi manajamen lembaga pendidikan yang akan turut menentukan kelancaran kegiatan pondok pesantren. Seperti halnya yang terjadi pada substansi manajemen pendidikan pada umumnya, kegiatan manajemen keuangan pondok pesantren seyogyanya dilakukan melalui proses perencanaan, pengorganisasian, pengarahan, pengkoordinasian, pengawasan atau pengendalian. Beberapa kegiatan manajemen keuangan berupa kegiatan memperoleh dan menetapkan sumber-sumber pendanaan, pemanfaatan dana, pelaporan, pemeriksaan dan pertanggung jawaban.

Pondok pesantren yang pada awalnya dianggap sebagai lembaga pendidikan alternatif, dewasa ini sudah mengalai kenaikan kasta menjadi lembaga pendidikan solutif dan substantif. Saat ini pondok pesantren dianggap satu-satunya lembaga pendidikan yang tetap eksis membentuk karakter dan kepribadian (personality character) generasi penerus bangsa ini.

Ada tiga faktor yang berperan dalam sistem penyelenggaraan Pondok Pesantren yaitu, manajemen sebagai faktor upaya, organisasi sebagai faktor Sarana, dan administrasi sebagai faktor karsa. Ketiga faktor ini memberi arah dan perpaduan dalam merumuskan, mengendalikan, penyelenggaraan, mengawasi serta menilai pelaksanaan kebijakan kebijakan dalam usaha menyelenggarakan kegiatan pendidikan yang sesuai dengan tujuan setiap Pondok Pesantren.

Pondok pesantren sebagai lembaga pendidikan Islam tertua di Indonesia, saat ini telah banyak mengalami pergeseran orientasi dari format salaf ke modern sehingga berdampak pada kemampuan para santri dalam menguasai ilmu keIslaman dari sumber-sumber klasik (thuras). Maka, untuk mengembalikan posisi ke peran semula, yaitu melahirkan kader-kader ulama tentunya dengan melakukan pembenahan baik pada sisi internal maupun eksternal lembaga secara tersistematis dan terorganisir agar out put-nya kelak memiliki keunggulan totalitas yakni tidak hanya unggul dalam kajian kitab-kitab klasik semata namun juga unggul dalam pengetahuan umum, manajemen, dan administrasi sebagai penyeimbang dari kemajuan zaman.

Azyumardi Azra dalam pengantar buku Bilik-bilik Pesantren karya Nurcholis Madjid mengatakan bahwa modernisasi sistem pendidikan pesantren mencakup empat hal. pertama, pembaharuan substansi atau isi pendidikan dengan memusatkan subjek-subjek umum dan vocational; kedua, pembaruan metodologi; ketiga, pembaruan kelembagaan; dan keempat, pembaruan fungsi ${ }^{4}$.

Menurut Pupuh Fathurahman dalam Priatna (peny.), sejalan dengan tuntutan dan kebutuhan masyarakat serta perkembangan zaman, dewasa ini banyak pondok pesantren yang menerapkan sistem pendidikan terpadu, yakni lembaga pendidikan pondok pesantren yang memiliki kondisi obyektif, baik secara kultural, manajemen, maupun pengelolaan kelembagaan yang terintegrasi dengan sistem sekolah atau madrasah yang berada di lingkungan pesantren ${ }^{5}$.

\footnotetext{
${ }^{4}$ Nurcholis Madjid, Bilik-bilik Pesantren Sebuah Potret Perjalanan, (Jakarta: Paramadina 1997), xxii

5 Tedi Priatna (peny.), Cakrawala Pemikiran Pendidikan Islam, (Bandung: Mimbar Pustaka, 2004). 195
} 
Eksistensi pondok pesantren saat ini menurut Muhtarom bahwa pondok pesantren tradisional sebagai lembaga dan wahana pendidikan Islam yang mengandung makna indigenous (asli) Indonesia telah ikut serta mencerdaskan kehidupan bangsa, mentransfer ilmu-ilmu keIslaman, memelihara tradisi keIslaman, mereproduksi ulama dan mentransmisikan Islam6

Lebih lanjut menurut Muhtarom salah satu faktor penentu keberhasilan pendidikan termasuk pendidikan pesantren adalah efektivitas manajemennya ${ }^{7}$. Manajemen pendidikan pesantren tidak jauh berbeda dengan manajemen pada umumnya. Manajemen pendidikan pesantren disebut juga manajemen pendidikan Islam

Pada pengelolaan manajemen pondok pesantren peran Kyai sangat besar dalam menentukan tujuan dan kegiatan manajerial yang harus dilakukan. Keadaan ini telah menjadikan hampir seluruh pengelolaan sumberdaya baik fisik ataupun finansial banyak ditangani langsung oleh Kyai atau oleh Keluarga Kyai dengan bantuan Ketua Pengurus (Santri) pondok pesantren peran yang dipercaya untuk melaksanakan kegiatan pondok pesantren peran dan lembaga pendidikan formal lainnya dibawah naungan pendidikan pondok pesantren. Secara umum, kepengurusan dalam pondok pesantren terdiri dari kyai, pengurus pondok pesantren, pimpinan unit-unit kegiatan dan tenaga kesekretariatan pondok pesantren dan guru/ustadz sebagai tenaga pengajar.

Pondok pesantren sebagai salah satu lembaga yang telah diakui oleh pemerintah. Merujuk pada Undang-undang Nomor 20 tahun 2003 tentang Sistem Pendidikan Nasional, posisi dan keberadaan pondok pesantren sebenarnya memiliki tempat yang istimewa. Namun, kenyataan ini belum disadari oleh mayoritas masyarakat muslim,. Karena kelahiran Undang-undang ini masih amat belia dan belum familiar dikalangan pondok pesantren di Indonesia. Keistimewaan pondok pesantren dalam sistem pendidikan nasional dapat kita lihat dari ketentuan dan penjelasan pasal-pasal dalam Undang-udang Sisdiknas sebagai berikut:

Dalam Pasal 3 UU Sisdiknas dijelaskan bahwa Pendidikan nasional berfungsi mengembangkan kemampuan dan membentuk watak serta peradaban bangsa yang bermartabat dalam rangka mencerdaskan kehidupan bangsa, bertujuan untuk berkembangnya potensi peserta didik agar menjadi manusia yang beriman dan bertakwa kepada Tuhan Yang Maha Esa, berakhlak mulia, sehat, berilmu, cakap, kreatif, mandiri, dan menjadi warga negara yang demokratis serta bertanggung jawab ${ }^{8}$. Ketentuan ini tentu saja sudah berlaku dan diimplementasikan di pondok pesantren.

Pondok pesantren sudah sejak lama menjadi lembaga yang membentuk watak dan peradaban bangsa serta mencerdaskan kehidupan bangsa yang

\footnotetext{
${ }^{6}$ Muhtarom, H.M., Reproduksi Ulama di Era Globalisasi Resistensi Tradisi Islam, (Yogyakarta: Pustaka Pelajar, 2005). 11

7 Muhtarom, H.M., Reproduksi Ulama di Era Globalisasi Resistensi Tradisi Islam, (Yogyakarta: Pustaka Pelajar, 2005). 17

${ }^{8}$ Undang-Undang No. 20 Tahun 2003 Tentang Sistem Pendidikan Nasional
} 
berbasis pada keimanan dan ketakwaan kepada Allah SWT serta akhlak mulia. Sehingga format Pesantren kedepan haruslah mampu bersaing dengan lembagalembaga pendidikan yang lain dengan menata kembali manajemen yang sejalan dengan perkembangan dan kebutuhan zaman.

Sering ditemukan bahwa di banyak pondok pesantren masalah keuangan selalu menjadi kendala dalam melakukan aktivitas Pesantren, baik yang berkaitan dengan angaran, akutansi, penataan administrasi, alokasi serta kebutuhan pengembangan Pesantren maupun dalam proses aktivitas keseharian Pesantren. Tidak sedikit Pesantren yang memiliki sumberdaya baik manusia maupun alamnya tidak tertata dengan rapi, dan tidak sedikit pula proses pendidikan pondok pesantren berjalan lambat karena kesalahan dalam penataan menejemen keuanganya.

Sebagai implementasi dari paradigma manajemen pendidikan yang ada di indonesia, Total Quality Manajemen (TQM), masalah keuangan dan pembiayaan menjadi lebih banyak di atur oleh lembaga pendidikan itu sendiri, tidak terkecuali pondok pesantren. Walaupun sebenarnya pondok pesantren dari dahulu sejak awal berdirinya memang adalah lembaga yang mandiri dalam penataan manajemenya. Namun alangkah lebih baik jika Pesantren bisa mengadopsi penataan manajemen yang bisa membawa kemaslahatan umat. Hal ini tentunya tidak terlepas dari prinsip Pesantren, (al-Muhafadhoh 'ala al-Qodim as-Sholih - wa alAkhdu bi al-Jadid al-Ashlah) melestarikan tradisi lama yang baik dan mengadopsi hal-hal baru yang lebih membawa mashlahat".

Problematika manajemen keuangan pondok pesantren tidak hanya ditemukan pada pengelolaan keuangan pondok pesantren tetapi juga pada lembaga pendidikan formal dan non formal yang ada dibawahnya. Lembaga pendidikan formal dan non formal yang dimaksud mulai dari PAUD, RA, TK, MI, MTs, MA bahkan pada perguruan tinggi.

\section{Konsep Dasar Manajemen Keuangan Pondok Pesantren}

Manajemen keuangan pondok pesantren adalah suatu proses dalam pengaturan aktivitas atau kegiatan keuangan pada suatu pondok pesantren dan lembaga pendidikan yang berada didalamnya, di dalamnya termasuk kegiatan planning, analisis dan pengendalian terhadap kegiatan keuangan yang biasanya dilakukan oleh ketua pengurus dan bendahara, dan atau kepala madrasah bersama bendahara madrasah pada sektor lembaga pendidikan formal yang ada dibawah naungan institusi pondok pesantren.

Manajemen keuangan pondok pesantren merupakan seluruh aktivitas kegiatan yang berhubungan dengan upaya untuk mendapatkan dana dengan meminimalkan biaya serta upaya penggunaan dan pengalokasian dana tersebut secara efektif dan efesien. Upaya tersebut bisa berupa pengembangan usaha pesantren, keputusan untuk berinvestasi, dan pengelolaan keuangan lainnya yang dilakukan secara syar'i dan fiqih muamalah dalam Islam.

\footnotetext{
${ }_{9}^{9}$ Ahmad Muthohar, Ideologi Pendidikan Pesantren, (Semarang: Pustaka Rizki Putra. 2007), 109
} 
Fungsi manajemen keuangan dalam pondok pesantren adalah untuk melaksanakan kegiatan agar suatu tujuan tercapai dengan efektif dan efisien. Secara tegas tidak ada rumusan yang sama dan berlaku umum untuk fungsi manajemen ${ }^{10}$.

Manajemen keuangan pondok pesantren memiliki tiga fungsi, yaitu: (1) Investment Decision (Menetapkan pengalokasian dana), (2) Financial Decision (Memutuskan alternatif pembiayaan), dan (3) Dividend Decision (Kebijakan dalam pembagian dividen) ${ }^{11}$.

Investment Decision adalah keputusan yang diambil oleh pemilik kebijakan keuangan pondok pesantren (ketua pengurus) dan lembaga (institusi) yang berada dibawah naungan pondok pesantren, seperti kepala madrasah (MI/MTs/MA) atau ketua lembaga pendidikan formal lainnya seperti PTKIS (Perguruan Tinggi Keagamaan Islam); tentang pengalokasian keuangan madrasah atau PTKIS dalam bentuk investasi yang dapat menghasilkan keuntungan (laba) di masa yang akan datang. Keputusan ini akan tergambar dari aktiva pesantren aktiva madrasah, dan aktiva PTKIS, serta mempengaruhi struktur keuangan yang dimiliki; yaitu perbandingan antara current assets (Aktiva Lancer) dengan fixed assets (Aset Tetap atau Aktiva Tetap) ${ }^{12}$.

Financial Decision adalah keputusan manajemen keuangan pemilik kebijakan keuangan pondok pesantren (ketua pengurus) dan lembaga (institusi) yang berada dibawah naungan pondok pesantren seperti kepala madrasah dalam melakukan pertimbangan dan analisis perpaduan antara sumber-sumber dana yang paling ekonomis bagi pesantren/madrasah untuk mendanai kebutuhankebutuhan investasi serta kegiatan operasional pesantren/madrasah. Keputusan pendanaan akan tercermin dalam sisi pasiva pondok pesantren, aktiva madrasah, dan aktiva PTKIS yang akan mempengaruhi financial structure (Struktur Keuangan) maupun capital structure (Struktur Modal) ${ }^{13}$.

Dividend Decision adalah kebijakan dalam pembagian dividen. Dividen merupakan bagian dari keuntungan pondok pesantren atau pemberian sebagian keuntungan dari lembaga pendidikan formal dibawahnya baik MI/MTs/MA/PTKIS. Keputusan dividen adalah keputusan manajemen keuangan dalam menentukan besarnya proporsi keuntungan (laba) yang akan dibagikan oleh lembaga formal dibawah pondok pesantren seperti madrasah kepada pondok pesantren sebagai lembaga pemilik dan proporsi dana yang akan disimpan di madrasah sebagai laba ditahan untuk pengembangan kegiatan madrasah selanjutnya. Kebijakan ini juga akan mempengaruhi financial structure (Struktur Keuangan) maupun capital structure (Struktur Modal) ${ }^{14}$.

\footnotetext{
${ }^{10}$ Tim Dosen Administrasi Pendidikan Universitas Pendidikan Indonesia. Manajemen Pendidikan, (Bandung: Alfabeta, 2009), 92

${ }^{11}$ Miftahol Arifin, Manajemen Keuangan Pendidikan, (Sumenep: Madura Press, 2013), 23

${ }^{12}$ Miftahol Arifin, Manajemen Keuangan Pendidikan, (Sumenep: Madura Press, 2013), 24

${ }^{13}$ Miftahol Arifin, Manajemen Keuangan Pendidikan, (Sumenep: Madura Press, 2013), 25

${ }^{14}$ Miftahol Arifin, Manajemen Keuangan Pendidikan, (Sumenep: Madura Press, 2013), 26
} 


\section{Tujuan Manajemen Keuangan Pondok Pesantren}

Melalui kegiatan manajemen keuangan maka kebutuhan pendanaan kegiatan pondok pesantren dapat direncanakan, diupayakan pengadaannya, dibukukan secara transparan, dan digunakan untuk membiayai pelaksanaan program pondok pesantren secara efektif dan efisien. Untuk itu tujuan manajemen keuangan pondok pesantren meliputi: (1) Meningkatkan efektivitas dan efisiensi penggunaan keuangan pondok pesantren; (2) Meningkatkan akuntabilitas dan transparansi keuangan pondok pesantren; dan (3) Meminimalkan penyalahgunaan anggaran pondok pesantren ${ }^{15}$.

Untuk mencapai tujuan tersebut, maka dibutuhkan kreativitas pengurus pesantren dalam menggali sumber-sumber dana, menempatkan bendaharawan yang menguasai dalam pembukuan dan pertanggung-jawaban keuangan serta memanfaatkannya secara benar sesuai AD/ART pondok pesantren dan peraturan perundangan yang berlaku.

\section{Prinsip Dasar Manajemen Keuangan Pondok Pesantren}

Pengurus pondok pesantren yang mengelola pendidikan formal selain harus memahami mikanisme aturan anggaran pendapatan dan pembelanjaan pondok pesantren, sitematika pelaporan dan pertanggungjawaban keuangan baik kepada pengasuh, biro keuangan, maupun badan pemeriksa keuangan sebagai badan pengaudit internal pondok pesantren; pengurus pesantren harus memahami prinsip-prinsip manajemen keuangan lembaga pendidikan formal yang digambarkan dalam undang-undang No 20 Tahun 2003. Pada pasal 48 menyatakan bahwa pengelolaan dana pendidikan berdasarkan pada prinsip keadilan, efisiensi, transparansi, dan akuntabilitas publik ${ }^{16}$. Disamping itu prinsip efektivitas juga perlu mendapat penekanan.

\section{Transparansi.}

Transparan berarti adanya keterbukaan. Transparan di bidang manajemen berarti adanya keterbukaan dalam mengelola suatu kegiatan ${ }^{17}$. Di pondok pesantren, bidang manajemen keuangan yang transparan berarti adanya keterbukaan dalam manajemen keuangan pondok pesantren, yaitu keterbukaan sumber keuangan dan jumlahnya, rincian penggunaan, dan pertanggungjawabannya harus jelas sehingga bisa memudahkan pihak-pihak yang berkepentingan untuk mengetahuinya.

Transparansi keuangan sangat diperlukan dalam rangka meningkatkan dukungan orang tua wali santri, masyarakat dan pemerintah dalam penyelenggaraan seluruh program pendidikan pondok pesantren. Disamping itu transparansi dapat menciptakan kepercayaan timbal balik antara pemerintah,

\footnotetext{
${ }^{15}$ Kadarman Jusuf, Pengantar Ilmu Manajemen, ( Jakarta: PT Gramedia Pustaka Utama, 1992), 18

${ }^{16}$ Undang-undang No. 20 Tahun 2003 tentang Sistem Pendidikan Nasional.

${ }^{17}$ Direktorat Tenaga Kependidikan. Direktorat Jenderal Peningkatan Mutu Pendidik dan Tenaga Kependidikan. Materi Pembinaan Profesi Kepala Sekolah/Madrasah. 2007. Departemen Pendidikan Nasional., 9
} 
masyarakat, orang tua siswa dan warga sekolah melalui penyediaan informasi dan menjamin kemudahan di dalam memperoleh informasi yang akurat dan memadai.

Beberapa informasi keuangan yang bebas diketahui oleh semua warga sekolah dan orang tua siswa misalnya rencana anggaran pendapatan dan belanja sekolah (RAPBS) bisa ditempel di papan pengumuman di ruang guru atau di depan ruang tata usaha sehingga bagi siapa saja yang membutuhkan informasi itu dapat dengan mudah mendapatkannya. Orang tua siswa bisa mengetahui berapa jumlah uang yang diterima sekolah dari orang tua siswa dan digunakan untuk apa saja uang itu. Perolehan informasi ini menambah kepercayaan orang tua siswa terhadap sekolah.

\section{Akuntabilitas}

Akuntabilitas adalah kondisi seseorang yang dinilai oleh orang lain karena kualitas performansinya dalam menyelesaikan tugas untuk mencapai tujuan yang menjadi tanggung jawabnya ${ }^{18}$. Akuntabilitas di dalam manajemen keuangan pondok pesantren berarti penggunaan uang pondok pesantren dapat dipertanggungjawabkan sesuai dengan perencanaan yang telah ditetapkan. Berdasarkan perencanaan yang telah ditetapkan dan peraturan yang berlaku maka pihak pondok pesantren dan lembaga formal dibawahnya membelanjakan uang secara bertanggung jawab. Pertanggungjawaban dapat dilakukan kepada pengasuh, badan pemeriksan keuangan pesantren, orang tua wali santri, masyarakat dan pemerintah.

Ada tiga pilar utama yang menjadi prasyarat terbangunnya akuntabilitas, yaitu:

1. adanya transparansi para penyelenggara sekolah dengan menerima masukan dan mengikutsertakan berbagai komponen dalam mengelola sekolah ,

2. adanya standar kinerja di setiap institusi yang dapat diukur dalam melaksanakan tugas, fungsi dan wewenangnya,

3. adanya partisipasi untuk saling menciptakan suasana kondusif dalam menciptakan pelayanan masyarakat dengan prosedur yang mudah, biaya yang murah dan pelayanan yang cepat ${ }^{19}$

\section{Efektivitas}

Efektif seringkali diartikan sebagai pencapaian tujuan yang telah ditetapkan. Garner (2004) mendefinisikan efektivitas lebih dalam lagi, karena sebenarnya efektivitas tidak berhenti sampai tujuan tercapai tetapi sampai pada

${ }^{18}$ Direktorat Tenaga Kependidikan. Direktorat Jenderal Peningkatan Mutu Pendidik dan Tenaga Kependidikan. Materi Pembinaan Profesi Kepala Sekolah/Madrasah. 2007. Departemen Pendidikan Nasional., 13

${ }^{19}$ Direktorat Tenaga Kependidikan. Direktorat Jenderal Peningkatan Mutu Pendidik dan Tenaga Kependidikan. Materi Pembinaan Profesi Kepala Sekolah/Madrasah. 2007. Departemen Pendidikan Nasional., 14 
kualitatif hasil yang dikaitkan dengan pencapaian visi lembaga. Effectiveness "characterized by qualitative outcomes". 20

Efektivitas lebih menekankan pada kualitatif outcomes. Manajemen keuangan pondok pesantren dikatakan memenuhi prinsip efektivitas kalau kegiatan yang dilakukan pondok pesantren dapat mengatur keuangan untuk membiayai aktivitas dalam rangka mencapai tujuan pondok pesantren dengan kualitatif outcomes-nya sesuai dengan rencana yang telah ditetapkan.

\section{Efisiensi}

Efisiensi berkaitan dengan kuantitas hasil suatu kegiatan. Efficiency"characterized by quantitative outputs" (Garner,2004). Efisiensi adalah perbandingan yang terbaik antara masukan (input) dan keluaran (out put) atau antara daya dan hasil21. Daya yang dimaksud meliputi tenaga, pikiran, waktu, biaya.

Perbandingan tersebut dapat dilihat dari dua hal:

a. Dilihat dari segi penggunaan waktu, tenaga dan biaya:

Kegiatan dapat dikatakan efisien kalau penggunaan waktu, tenaga dan biaya yang sekecil-kecilnya dapat mencapai hasil yang ditetapkan.

b. Dilihat dari segi hasil

Kegiatan dapat dikatakan efisien kalau dengan penggunaan waktu, tenaga dan biaya tertentu memberikan hasil sebanyak-banyaknya baik kuantitas maupun kualitasnya.

Tingkat efisiensi dan efektivitas yang tinggi memungkinkan terselenggaranya pelayanan terhadap masyarakat secara memuaskan dengan menggunakan sumber daya yang tersedia secara optimal dan bertanggung jawab.

\section{Tiga Tahap Manajemen Keuangan Pondok Pesantren}

Manajemen keuangan pondok pesantren memiliki tiga tahapan penting yaitu tahap perencanaan (budgeting), tahap pelaksanaan (Akunting) dan tahap penilaian atau evaluasi (Auditing). Ketiga tahapan tersebut harus dilakukan dalam pengelolaan manajemen keuangan pondok pesantren agar keuangan pondok pesantren dan lembaga formal maupun non formal didalamnya sehat, dinamis dan akuntabel.

\section{Penganggaran (budgeting)}

Perencanaan atau Penganggaran (budgeting) merupakan kegiatan atau proses penyusunan anggaran. Budget merupakan rencana operasional yang

${ }^{20}$ Direktorat Tenaga Kependidikan. Direktorat Jenderal Peningkatan Mutu Pendidik dan Tenaga Kependidikan. Materi Pembinaan Profesi Kepala Sekolah/Madrasah. 2007. Departemen Pendidikan Nasional., 18

${ }^{21}$ Direktorat Tenaga Kependidikan. Direktorat Jenderal Peningkatan Mutu Pendidik dan Tenaga Kependidikan. Materi Pembinaan Profesi Kepala Sekolah/Madrasah. 2007. Departemen Pendidikan Nasional., 21 
dinyatakan secara kuantitatif dalam bentuk satuan uang yang digunakan sebagai pedoman dalam pelaksanaan kegiatan-kegiatan lembaga dalam kurun waktu tertentu ${ }^{22}$. Lebih jauh Nanang Fatah menjelaskan dalam menentukan biaya satuan pendidikan terdapat dua pendekatan yaitu pendekatan makro dan pendekatan mikro. Pendekatan makro mendasarkan perhitungan pada keseluruhan jumlah pengeluaran pendidikan yang diterima dari berbagai sumber dana kemudian dibagi jumlah murid.

Morphet (1975) sebagaimana dikutip Mulyasa menjelaskan tentang hal-hal yang perlu diperhatikan dalam penganggaran biaya pendidikan. Pertama, anggaran belanja harus dapat mengganti beberapa peraturan dan prosedur yang tidak efektif sesuai dengan kebutuhan pendidikan; Kedua, merevisi peraturan dan input lain yang relevan, dengan mengembangkan perencanaan sistem yang efektif; dan Ketiga, memonitor dan menilai keluaran pembiayaan secara terus menerus dan berkesinambungan sebagai bahan perencanaan tahap penggaran tahun berikutnya ${ }^{23}$.

Untuk mengefektifkan pembuatan perencanaan keuangan pondok pesantren, maka yang sangat bertanggung jawab sebagai pelaksana ketua pengurus pondok pesantren. Jika lembaga pendidikan formal dibawah pondok pesantren adalah kepala madrasah. Ketua pengurus pondok pesantren dan kepala madrasah harus mampu mengembangkan sejumlah dimensi pengembangan administratif.

Untuk penganggaran minimal ada dua format yang harus dilakukan yang pertama RKA (Rencana Kegiatan Anggaran), biasa disebut RKAS (Rencana Kegiatan Anggaran Sekolah atau RKAPP (Rencana Kegiatan Anggaran Pondok Pesantren); dan RAPB (Rencana Anggaran Penerimaan dan Belanja), biasa disebut RAPBS (Rencana Anggaran Penerimaan dan Belanja Sekolah), RAPBM (Rencana Anggaran Penerimaan dan Belanja Madrasah), atau RAPBPP (Rencana Anggaran Penerimaan dan Belanja Pondok Pesantren). Analisis penyususnan RKA dan RAPB memerlukan analisis masa lalu dan lingkungan ekstern (SWOT) yang mencakup kekuatan (strength), kelemahan (weakness), peluang (opportunities) dan ancaman (threats).

\section{Pelaksanaan (Akunting)}

Akunting adalah bahasa yang digunakan untuk menggambarkan hasil kegiatan ekonomi24. Menurut Mulyasa dalam pelaksanaan keuangan dalam garis besarnya dapat dikelompokan ke dalam dua kegiatan, yakni penerimaan dan pengeluaran ${ }^{25}$. Penerimaan dan pengeluaran keuangan pondok pesantren yang diperoleh dari sumber-sumber dana perlu dibukukan berdasarkan prosedur pengelolaan yang selaras dengan kesepakatan yang telah disepakati, baik berupa konsep teoritis maupun peraturan pemerintah. Misalnya penerimaan dana dari

\footnotetext{
${ }^{22}$ Nanang Fatah, Ekonomi dan Pembiayaan Pendidikan, (Bandung: Remaja Rosdakarya, 2000), 47

${ }^{23}$ E. Mulyasa, Manajemen Berbasis Sekolah, (Bandung: Remaja Rosdakarya, 2006), 196

${ }^{24}$ Tim Dosen Administrasi Pendidikan Universitas Pendidikan Indonesia. Manajemen Pendidikan, (Bandung: Alfabeta, 2009). 265

${ }^{25}$ E. Mulyasa, Manajemen Berbasis Sekolah, (Bandung: Remaja Rosdakarya, 2006), 201
} 
SPP (Sahriyah) santri tercatat dalam Buku Penerimaan SPP (Sahriyah) serta ada bukti penerimaan berupa Buku Kartu SPP (Sahriyah) Santri yang dipegang santri. Keduanya dilengkapi dengan Buku Administrasi Penyetoran dan Penerimaan SPP (Sahriyah). Selain itu bila pondok pesantren yang dimaksud memiliki donator tetap maka perlu disediakan Buku Penerimaan Donasi.

Pada proses pelaksanaan selain buku-buku tersebut ada buku utama yang wajib diisi setiap terjadi transaksi, yaitu Buku KAS Umum. Buku KAS Umum ini yang menggambarkan history penerimaan dan pengeluaran dana pondok pesantren. Buku KAS Umum tersebut dilengkapi dengan dokumen Bukti KAS yang berupa kwitansi, faktur, nota, atau catatan administrasi lainnya. Salah satu Bukti KAS yang berupa catatan administrasi ialah Buku Honorarium dan Intensif Asatidz dan Staf (Pegawai).

\section{Evaluasi (Auditing)}

Auditing adalah proses pengumpulan dan pengevaluasian bahan bukti tentang informasi yang dapat diukur mengenai suatu entitas ekonomi yang dilakukan seorang yang kompeten dan independen untuk dapat melaporkan kesesuaian informasi dimaksud dengan kriteria-kriteria yang telah ditetapkan ${ }^{26}$. Sedangkan menurut Mulyasa dalam evaluasi keuangan sekolah, pengawasan merupakan salah satu proses yang harus dilakukan dalam manajemen pembiayaan berbasis sekolah ${ }^{27}$. Pada keuangan manajemen pondok pesantren, ketua pengurus pondok pesantren perlu melakukan pengendalian pengeluaran keuangan pondok pesantren selaras dengan RAPB yang telah ditetapkan.

Menurut Nanang Fattah secara sederhana proses pengawasan terdiri dari tiga kegiatan, yaitu memanatau (monitoring), menilai dan melaporkan ${ }^{28}$. Proses evaluasi ini dilakukan untuk dan agar kegiatan-kegiatan yang berkaitan dengan manajemen keuangan berjalan secara efektif dan efisien dan tidak terjadi penyimpangan-penyimpangan dalam prosesnya. Disinilah seorang ketua pengurus pondok pesantren harus memantau dan menilai hasilnya. Ada beberapa jenis-jenis Auditing:

1. Audit Laporan Keuangan, Audit laporan keuangan bertujuan menentukan apakah laporan keuangan secara keseluruhan yang merupakan informasi terukur yang akan diverifikasi,telah disajikan sesuai dengan kriteria-kriteria tertentu.

2. Audit Operasional, Audit operasional merupakan penelaahan atas bagian manapun dari prosedur dan metode operasi suatu organisasi untuk menilai efisiensi dan efektitasnya. Umumnya, pada saat selesainya audit operasional, auditor akan memberikan sejumlah saran kepada manajemem untuk memperbaiki jalannya operasi pondok pesantren.

\footnotetext{
${ }^{26}$ Tim Dosen Administrasi Pendidikan Universitas Pendidikan Indonesia. Manajemen Pendidikan, (Bandung: Alfabeta, 2009). 265

${ }^{27}$ E. Mulyasa, Manajemen Berbasis Sekolah, (Bandung: Remaja Rosdakarya, 2006), 205

${ }^{28}$ Nanang Fatah, Ekonomi dan Pembiayaan Pendidikan, (Bandung: Remaja Rosdakarya, 2000), 66
} 
3. Audit Ketaatan, Audit ketaatan bertujuan mempertimbangkan apakah auditi (klien) telah mengikuti prosedur atau aturan tertentu yang telah ditetapkan pihak yang memiliki otoritas lebih tinggi. Suatu audit ketaatan pada lembaga (perusahaan) swasta, dapat termasuk penentuan apakah para pelaksana akuntasi telah mengikuti prosedur yang telah ditetepkan oleh lembaga. Contoh peninjauan tingkat upah,pemeriksaan perjanjian dengan pihak lain (seperti bank/kreditor), dan memenuhi ketentuan hokum yang berlaku.

\section{Problematika Manajemen Keuangan Pondok Pesantren}

Manajemen keuangan pondok pesantren tidak lepas dari berbagai masalah. Di antara masalah-masalah tersebut adalah, lemahnya SDM pengurus, minimnya dana operasional, penyalahgunaan keuangan, membebankan pembiayaan kepada santri, pelaporan keuangan yang penuh manipulasi dan spekulasi, pembelanjaan keuangan yang tidak tepat guna, dan lain sebagainya.

Tak dapat dipungkiri sebagian besar pondok pesantren memiliki keterbatasan SDM yang mumuni dalam manajemen keuangan. Diperparah lagi dengan tidak dilaksanakannya pelatihan tentang manajemen keuangan. Hal ini yang menyebabkan pondok pesantren kesulitan dalam membuat dan menganalisis RAPB dan merealisasikannya sesuai RAPB, serta sulitnya membuat laporan keuangan pondok pesantren yang akutabel dan transparan.

Kurangnya dana operasional pondok pesantren khususnya pondok pesantren yang memiliki santri sedikit, dan minimnya intensif yang diterima para pengurus tidak sedikit menyebabkan terjadinya penyalahgunaan keuangan dan penyalahgunaan kebijakan keuangan.

Penyalahgunaan keuangan memang sudah menjamur di mana-mana, baik instansi swasta maupun negeri, termasuk juga di pondok pesantren. Penyalahgunaan keuangan adalah tindakan manipulasi data keuangan dan sengaja melakukan kebijakan spekulatif dalam pembelajaan, termasuk yang paling parah memperkaya diri dengan berbagai cara yang melanggar aturan hukum dan tata tertib pondok pesantren. Walau tidak banyak terjadi di institusi pondok pesantren penyalahgunaan keuangan biasanya sering terjadi dibagian ketua pengurus, bendahara, pimpinan usaha milik pondok pesantren, dan jabatan-jabatan lain yang berkuasa menentukan kebijakan dan atau pememegang langsung uang pondok pesantren.

Mereka memiliki keleluasaan dalam mengendalikan uang. Kebijakankebijakan yang di keluarkan kadang-kadang tidak sesuai dengan apa yang sudah direncanakan dalam Rencana Anggaran Belanja Pondok Pesantren. Sayangnya penyalahgunaan keuangan di pondok pesantren seringkali dibiarkan oleh pengsuh pondok pesantren. Hal ini terjadi di pondok pesantren lebih utama menutupi penyalahgunaan keuangan di pondok pesantren dari khalayak umum karena dianggap aib. Dibiarkan maksudnya tidak sampai dibawa ke pengadilan atau dipolisikan tetapi sebatas dipulangkan dan tidak ada tuntutan untuk mengembalikan uang yang telah dikorupsinya.

Pungutan dana illegal dan usaha-usaha lain yang menghasilkan dana dilakukan tanpa sepengetahuan pengasuh seringkali terjadi dan dilakukan oleh 
oknum pengurus dan pengelola pondok pesantren. Hal ini sering terjadi karena perputaran keuangan di pondok pesantren cendrung tertutup. Pelaporan keuangan yang akuntabel dan transparan juga terabaikan. Oleh karena itu bagi pengasuh pondok pesantren yang memahami terjadinya potensi penyalahgunaan keuangan mendirikan badan independen audit internal untuk mengawasi realisasi anggaran dan memeriksa laporan keuangan pondok pesantren.

\section{Penutup}

Manajemen keuangan pondok pesantren merupakan salah satu substansi manajamen pondok pesantren yang akan turut menentukan berjalannya kegiatan kegiatan pondok pesantren. Sebagaimana yang terjadi di substansi manajemen pendidikan pada umumnya, kegiatan manajemen keuangan pondok pesantren dilakukan melalui proses perencanaan, pengorganisasian, pengarahan, pengkoordinasian, pengawasan atau pengendalian. Adapun tujuan dari manajemen keuangan pondok pesantren adalah untuk memperoleh, dan mencari peluang sumber-sumber pendanaan bagi kegiatan sekolah, agar bisa menggunakan dana secara efektif dan efisien, tidak melanggar aturan, dan membuat laporan keuangan yang transparan serta akuntabel.

Ada tiga tahap manajemen keuangan pondok pesantren, yaitu tahap perencanaan (budgeting), tahap pelaksanaan (Akunting) dan tahap penilaian atau evaluasi (Auditing) yang perlu diperhatikan dan dilaksanakan agar manajemen keuangan pondok pesantren sehat; sehat perencanaan, sehat pengelolaan dan sehat pelaporan. Selain itu akan menjadikan pondok pesantren terhindar dari penyalahgunaan keuangan dan penyalahgunaan kebijakan.

\section{DAFTAR PUSTAKA}

Ahmad Muthohar, Ideologi Pendidikan Pesantren, (Semarang: Pustaka Rizki Putra. 2007)

Akhmad Sudrajat, Konsep dasar manajemen keuangan sekolah, (Semarang: Pustaka Rizki Putra, 2013), 36.

Direktorat Tenaga Kependidikan. Direktorat Jenderal Peningkatan Mutu Pendidik dan Tenaga Kependidikan. Materi Pembinaan Profesi Kepala Sekolah/Madrasah. 2007. Departemen Pendidikan Nasional., 9

E. Mulyasa, Manajemen Berbasis Sekolah, (Bandung: Remaja Rosdakarya, 2006)

Kadarman Jusuf, Pengantar Ilmu Manajemen, ( Jakarta: PT Gramedia Pustaka Utama, 1992)

Miftahol Arifin, Manajemen Keuangan Pendidikan, (Sumenep: Madura Press, 2013), 23

Muhtarom, H.M., Reproduksi Ulama di Era Globalisasi Resistensi Tradisi Islam, 
(Yogyakarta: Pustaka Pelajar, 2005)

Nanang Fatah, Ekonomi dan Pembiayaan Pendidikan, (Bandung: Remaja Rosdakarya, 2000)

Nurcholis Madjid, Bilik-bilik Pesantren Sebuah Potret Perjalanan, (Jakarta: Paramadina 1997)

Sulistyorini, Manajemen Pendidikan Islam, (Yogyakarta: Teras, 2009)

Tedi Priatna (peny.), Cakrawala Pemikiran Pendidikan Islam, (Bandung: Mimbar Pustaka, 2004)

Tim Dosen Administrasi Pendidikan Universitas Pendidikan Indonesia. Manajemen Pendidikan, (Bandung: Alfabeta, 2009). 265

Undang-Undang No. 20 Tahun 2003 Tentang Sistem Pendidikan Nasional 